\title{
SECULAR TRENDS IN HEIGHT AND WEIGHT AMONG CHILDREN FROM NOVI SAD (SERBIA), 1971-2017
}

\author{
Tatjana M. Pavlica ${ }^{1}$, Rada S. Rakić ${ }^{1}$, Boris K. Popović ${ }^{2}$, \\ Valerija P. Puškaš ${ }^{1}$, Verica S. Božić-Krstić ${ }^{1}$ \\ ${ }^{1}$ Department of Biology and Ecology, Faculty of Sciences, University of Novi Sad, Serbia \\ ${ }^{2}$ Faculty of Sport and Physical Education, University of Novi Sad, Serbia
}

\begin{abstract}
Summary. The secular trend is biological indicator for assessing the degree of socio-economic development of a country. The study aims to analyze the secular trend of height and weight of children 3-11 aged in the city of Novi Sad (Serbia) in the period between 1971 and 2017. An anthropometric investigation was conducted six times within the stated period. The data are presented for a total of 13037 children (6969 boys; 6068 girls) on the territory of Novi Sad.The results point to a positive secular trend, although this is not observable in all ages and decades. The mean height of preschool boys and girls increased $0.21 \mathrm{~cm}$ and $0.11 \mathrm{~cm}$ per decade respectively, while in school boys and girls an increase was $0.70 \mathrm{~cm}$ and $0.55 \mathrm{~cm}$ per decade. The mean weight of preschool boys and girls increased $0.1 \mathrm{~kg}$ and $0.03 \mathrm{~cm}$ per decade respectively, while in school boys and girls an increase was $0.69 \mathrm{~kg}$ and $0.57 \mathrm{~kg}$ per decade. The magnitude of secular changes in body height and weight was not stable. These results possibly reflect a very turbulent socio-economic and political situation in the country, which began in the 1990s.
\end{abstract}

Key words: children, height, secular trend, Serbia, weight.

\section{Introduction}

Secular changes represent marked changes in growth processes and adult body size of successive generations in a given population (Malina, 1990; Bogin, 1999). They can be perceived as a natural biological experiment reflecting complex interaction of genes, physiology and the environment that all define the body shape and size from generation to generation (Cole, 2003). The secular trend is biological indicator that is used in auxology and for assessing the degree of socio-economic development of a country, which is important information for public health policies (Rao et al., 2012). Human biological characteristics are influenced by genetic factors and also by the natural and socio-economic environment.It is well known that height of individuals is a significant index of nutrition and health of a population (Akachi and Canning, 2007; Deaton, 2007). The positive secular trend in populations within the developing world has largely been attributed to improved nutrition, health conditions and socio-economic circumstances (Komlos, 1994). Negative secular change in a population's height is a response to environmental deterioration and has been observed in some contemporary populations (Neyzi et al., 1996; Akachi and Canning, 2007).On the other hand, Zellner et al. (2004) and Krawczynski et al. (2003) found a plateau in German and Polish children's height, respectively, which means that they achieved their full genetic potential and/or that their socio-economic conditions had ceased to improve. Additionally, positive changes have also been observed in weight all over the world reflecting

Autor za korespondenciju: Tatjana M. Pavlica, e-mail: tatjana.pavlica@dbe.uns.ac.rs

Prirodno-matematički Fakultet, Departman za biologiju i ekologiju, 21000 Novi Sad, Serbia

Primljeno u redakciju 31. 8. 2018, revidirana verzija 20. 10. 2018, rad prihvaćen za publikovanje 28. 10. 2018. 
recent increases in the prevalence of overweight/obesity in children (United Nations Children's Fund WHO 2012).

Secular changes in height and weight have been a focus of attention in various populations, but there is not enough data regarding Serbian population. Božić et al.(2004) published the results of height and weight of children aged $3-11$ in the periods between 1971, 1981, 1991 and 2001 in Novi Sad, the capital of Vojvodina Province (North Serbia). They found positive changes in height and weight in the decades 1971-1981 and 1981-1991. However, in the period between 1991 and 2001 both positive and negative changes were recorded, due to the change of politicaland economic situation in the country. In 1990, a political and economic crisis started, causing a rapid fall of gross domestic product and living standards. Lower values of height and weight recorded in 2001 were probably due to the changes in living conditions or they possibly indicate that the acceleration reached its peak.

When the outer wall of sanctions was lifted in 2000 Serbia regulated its relations with international political, economic and financial organizations and thus created better conditions for intense economic reforms and dynamic economic growth. However, considerable regional disproportions considering the level of human development appeared. In 2008 Human Development Index (HDI) in the Province of Vojvodina (North Serbia) was almost identical to the one referring to the whole country of Serbiaand the highest level of life quality was recorded in South Backa District where the city of Novi Sad, the capital of the Province of Vojvodina, is situated. The regime change in October 2000 and subsequent internationalization of Serbia created better conditions for further development of the city. After a period of deterioration due to the sanctions, the economy of the city of Novi Sad started strengthening. Apart from refugees and immigrants who came to Novi Sad during the war years, the city started attracting a new group of settlers, economic migrants. (http://www.politika.rs/scc/clanak/112039/Dunavskosavska-koncentracija). According to 2002 census, the Novi Sad population was 299.294 and in 2008 it reached 335.381. The data from 2009 document that $31 \%$ of the entire population lived either in the capital city (Belgrade) or in Novi Sad, creating $40 \%$ of the working population responsible for two thirds of the gross product and a half of the industrial income.

This study aims to describe the secular growth trend in height and weight in the city of Novi Sad after 2000 in order to provide information on the impact of socio-economic fluctuations on long-term changes in these characteristics. The study represents a continuation of the research that began in 1971.

\section{Subjects and Methods}

An anthropometric survey of children aged 3-11 was conducted six times and included a time interval of 46 years. Data are presented for a total of 13037 children (6969 boys; 6068 girls) examined on the territory of Novi Sad during this period. The first survey was performed in 1971 (Gavrilović 1972, Gavrilović et al., 1972), and the subsequent in 1981 (Božić-Krstić 1983), 1991 (Božić-Krstić et al., 2000), 2001, 2009 (Rakić, 2009) and 2017, following the instructions of the International Biological Program (Weiner and Lourie, 1969; Lohman et al., 1988). The data for the period 1971-2001 were already published (Božić-Krstić et al., 2004), but in order to obtain continuity and better insight into secular changes they are also presented here. The survey was conducted in pre-school institutions and primary schools situated in the center of the city of Novi Sad. 


\section{Data collection}

The data included children of Serbian nationality born in Novi Sad with similar socioeconomic background. According to the decimal age, the children were classified in age classes (e.g. a child aged 3 belongs to the age class 2.500-3.4900). Height and weight were measured using Martin's standard anthropometric instrument (produced by Sieber Hegner, Schweitz). Preschool children (aged 3-6) were measured in 1971, 2001, 2011 and 2017, while school children (aged 7-11) were measured in 1971, 1981, 1991, 2001, 2009 and 2017. The subjects were lightly dressed and without shoes and were measured in the morning hours. Body height was measured with an anthropometer in the standing erect position, to the nearest $0.1 \mathrm{~cm}$. Body weight was measured on electronic digital scale with an accuracy of up to $0.1 \mathrm{~kg}$.

\section{Statistical Analysis}

Arithmetical means with standard deviation $(\mathrm{Mean} \pm \mathrm{SD})$ for each group were calculated. One-Way ANOVA with Bonferroni Post-hoc test was used for detecting differences among the ages and the surveying periods and statistical difference was set at $p<0.05$. Sample data were analyzed using Statistica for Windows software, version 13. All surveys were approved by the Council of Department of Biology and Ecology, University of Novi Sad, whose responsibilities include dealing with bioethical issues. The written consent for measuring the children was obtained from the parents, Board of Management and school principals. Individual contacts were made with school psychologists and/or pedagogues. In pre-school institutions, the measurement of children was carried out after obtaining a consent from directors and heads of preschool institutions, as well as from children's parents.

\section{Rezultati}

Table 1 shows the sample size (n), the means, standard deviation (SD), F value and significance as well as the Bonferroni correction for multiple comparisons of boys and girls' height at a specific ages.

The means do not statistically differ at the ages of 3 and 4 in both boys and girls and at the ages 5 and 9 in girls. The greatest difference in height means is observed at the age of 11 in boys $(\mathrm{F}=12.013 ; \mathrm{P}=0.000)$ and at the age of 6 in girls $(\mathrm{F}=7.885 ; \mathrm{P}=0.000)$. The greatest increase in height in the period 1971-2017 is recorded at the age of 11 (8.1 and 4.2 $\mathrm{cm}$ in boys and girls, respectively). In 5-year old boys the significant height increase is seen in the period 2001 and $2011(\mathrm{P}<0.01)$. Considering pre-puberty age, the greatest differences are present in 6-year-old subjects. In the period of 40 years (1971-2011) the 6-year-old boys and girls have become taller by 2.7 and $2 \mathrm{~cm}$, respectively. In puberty age, the statistical difference in height is observed in all ages except the age of 9 in girls and the difference is most noticeable at the age of 11. During the five-decade period, the changes recorded in children aged 7 to 11 equal $3.5 \mathrm{~cm}$ in boys and $2.8 \mathrm{~cm}$ in girls, i.e. $0.7 \mathrm{~cm}$ in boys and $0.55 \mathrm{~cm}$ in girls per decade. 
Table 1. Body height of Novi Sad boys and girls in different years of investigation.

Tabela 1. Visina tela dečaka i devojčica u Novom Sadu u ispitivanim vremenskim periodima.

\begin{tabular}{|c|c|c|c|c|c|c|c|c|}
\hline \multirow[b]{2}{*}{ Age } & \multirow[b]{2}{*}{ Year } & \multicolumn{4}{|c|}{ Boys } & \multicolumn{3}{|c|}{ Girls } \\
\hline & & $\mathrm{n}$ & Mean & SD & $\begin{array}{l}\text { ANOVA F(p) } \\
\text { Bonferroni test }\end{array}$ & $\mathrm{n}$ & Mean SD & $\begin{array}{l}\text { ANOVA F(p) } \\
\text { Bonferroni test }\end{array}$ \\
\hline \multirow[t]{3}{*}{3} & $1971^{\mathrm{a}}$ & 71 & 100.1 & 4.3 & $2.570(0.078)$ & 63 & $99.4 \quad 4.8$ & $2.372(0.095)$ \\
\hline & $2001^{d}$ & 84 & 100.1 & 3.6 & & 78 & $97.9 \quad 3.8$ & \\
\hline & $2011^{\mathrm{g}}$ & 114 & 101.4 & 5.3 & & 110 & $99.0 \quad 4.3$ & \\
\hline \multirow[t]{4}{*}{4} & $1971^{\mathrm{a}}$ & 124 & 106.4 & 4.8 & $1.616(0.185)$ & 114 & 106.25 .4 & $0.887(0.413)$ \\
\hline & $2001^{d}$ & 123 & 106.2 & 4.6 & & 136 & $105.8 \quad 5.0$ & \\
\hline & $2011^{\mathrm{g}}$ & 129 & 107.3 & 5.9 & & 126 & 106.75 .3 & \\
\hline & $2017^{\mathrm{f}}$ & 67 & 107.4 & 3.9 & & - & - & \\
\hline \multirow[t]{4}{*}{5} & $1971^{\mathrm{a}}$ & 190 & 113.8 & 5.2 & $3.276(0.021)$ & 167 & 112.15 .1 & $2.129(0.120)$ \\
\hline & $2001^{d}$ & 161 & 112.6 & 5.1 & & 151 & 112.55 .0 & \\
\hline & $2011^{\mathrm{g}}$ & 124 & 114.5 & 5.2 & $\mathrm{~g} / \mathrm{d} * *$ & 105 & 113.45 .5 & \\
\hline & $2017^{\mathrm{f}}$ & 159 & 113.7 & 4.8 & & & & \\
\hline \multirow[t]{4}{*}{6} & $1971^{\mathrm{a}}$ & 425 & 119.0 & 5.3 & $10.460(0,000)$ & 367 & 118.15 .3 & $7.885(0.000)$ \\
\hline & $2001^{\mathrm{d}}$ & 202 & 120.0 & 6.1 & & 194 & 119.15 .3 & \\
\hline & $2011^{\mathrm{g}}$ & 143 & 121.7 & 5.8 & $\mathrm{~g} / \mathrm{a} * * * ; \mathrm{g} / \mathrm{d} *$ & 138 & 120.15 .1 & $\mathrm{~g} / \mathrm{a} * * *$ \\
\hline & $2017^{\mathrm{f}}$ & 158 & 121.1 & 5.5 & $\mathrm{f} / \mathrm{a}^{* * *}$ & - & - & \\
\hline \multirow[t]{6}{*}{7} & $1971^{\mathrm{a}}$ & 55 & 124.1 & 5.8 & $2.486(0.030)$ & 60 & $123.5 \quad 5.4$ & $2.739(0.018)$ \\
\hline & $1981^{b}$ & 352 & 125.4 & 5.4 & & 375 & 124.65 .1 & \\
\hline & $1991^{\mathrm{c}}$ & 115 & 126.7 & 5.6 & & 110 & 125.95 .2 & \\
\hline & $2001^{\mathrm{d}}$ & 178 & 125.8 & 5.7 & & 164 & 125.06 .1 & \\
\hline & $2009^{\mathrm{e}}$ & 60 & 126.9 & 5.1 & e/a* & 70 & 125.45 .7 & \\
\hline & $2017^{\mathrm{f}}$ & 127 & 125.9 & 5.6 & & 30 & $127.0 \quad 5.0$ & $\mathrm{f} / \mathrm{a}^{* *} ; \mathrm{f} / \mathrm{b}^{*}$ \\
\hline \multirow[t]{6}{*}{8} & $1971^{\mathrm{a}}$ & 76 & 130.3 & 7.0 & $5.573(0.000)$ & 69 & 128.95 .6 & $2.802(0.016)$ \\
\hline & $1981^{b}$ & 774 & 130.2 & 5.7 & & 389 & $130.0 \quad 5.9$ & \\
\hline & $1991^{\mathrm{c}}$ & 113 & 131.7 & 5.7 & & 112 & 129.45 .7 & \\
\hline & $2001^{\mathrm{d}}$ & 160 & 131.7 & 5.6 & & 167 & 130.66 .0 & \\
\hline & $2009^{\mathrm{e}}$ & 107 & 132.7 & 5.9 & $\mathrm{e} / \mathrm{b} * * *$ & 102 & 131.65 .1 & $\mathrm{e} / \mathrm{a}^{*}$ \\
\hline & $2017^{\mathrm{f}}$ & 43 & 131.9 & 5.3 & & 30 & 131.45 .8 & \\
\hline \multirow[t]{6}{*}{9} & $1971^{\mathrm{a}}$ & 75 & 135.7 & 6.0 & $2.249(0.048)$ & 62 & 135.35 .9 & $0.881(0.095)$ \\
\hline & $1981^{b}$ & 410 & 136.4 & 6.4 & & 408 & 135.96 .3 & \\
\hline & $1991^{c}$ & 114 & 136.7 & 4.8 & & 77 & 137.26 .0 & \\
\hline & $2001^{\mathrm{d}}$ & 164 & 136.3 & 6.5 & & 144 & 137.36 .4 & \\
\hline & $2009^{\mathrm{e}}$ & 92 & 136.7 & 6.6 & & 85 & 137.16 .7 & \\
\hline & $2017^{\mathrm{f}}$ & 32 & 139.9 & 7.2 & $\mathrm{f} / \mathrm{a}^{* *} ; \mathrm{f} / \mathrm{b}^{*}$ & 30 & 136.28 .3 & \\
\hline \multirow[t]{6}{*}{10} & $1971^{\mathrm{a}}$ & 64 & 140.5 & 5.5 & $2.901(0.013)$ & 54 & 140.68 .0 & $4.123(0.001)$ \\
\hline & $1981^{b}$ & 410 & 141.4 & 6.9 & & 403 & 141.17 .2 & \\
\hline & $1991^{c}$ & 118 & 143.2 & 6.6 & & 126 & 143.97 .0 & $\mathrm{c} / \mathrm{a}, \mathrm{f}^{*}$ \\
\hline & $2001^{\mathrm{d}}$ & 125 & 142.8 & 6.2 & & 110 & 142.77 .3 & \\
\hline & $2009^{\mathrm{e}}$ & 78 & 143.1 & 6.3 & & 106 & 141.96 .9 & \\
\hline & $2017^{\mathrm{f}}$ & 30 & 142.4 & 6.8 & & 30 & 144.03 .8 & \\
\hline \multirow[t]{6}{*}{11} & $1971^{\mathrm{a}}$ & 73 & 144.4 & 6.2 & $12.013(0.000)$ & 76 & 147.27 .0 & $5.124(0.000)$ \\
\hline & $1981^{b}$ & 397 & 146.9 & 7.0 & & 380 & 147.67 .3 & \\
\hline & $1991^{\mathrm{c}}$ & 114 & 147.1 & 7.0 & & 98 & 148.97 .2 & \\
\hline & $2001^{\mathrm{d}}$ & 89 & 145.5 & 7.0 & & 71 & 148.78 .1 & \\
\hline & $2009^{\mathrm{e}}$ & 85 & 149.0 & 6.5 & $\mathrm{e} / \mathrm{a} * * * ; \mathrm{e} / \mathrm{d} *$ & 92 & 150.37 .4 & $\mathrm{e} / \mathrm{b}^{*}$ \\
\hline & $2017^{\mathrm{f}}$ & 65 & 152.4 & 7.6 & $\mathrm{f} / \mathrm{a}, \mathrm{b}, \mathrm{c}, \mathrm{d}^{* * *} ; \mathrm{f} / \mathrm{d} *$ & 71 & 151.47 .2 & $\mathrm{f} / \mathrm{a}, \mathrm{b}^{* *}$ \\
\hline
\end{tabular}


The statistical indicators of the subjects' weight are given in Table 2.

Table 2. Body weight of Novi Sad boys and girls in different years of investigation.

Tabela 2. Masa tela dečaka i devojčica u Novom Sadu u ispitivanim vremenskim periodima.

\begin{tabular}{|c|c|c|c|c|c|c|c|c|}
\hline \multirow[b]{2}{*}{ Age } & \multirow[b]{2}{*}{ Year } & \multicolumn{4}{|c|}{ Boys } & \multicolumn{3}{|c|}{ Girls } \\
\hline & & $\mathrm{n}$ & Mean & SD & $\begin{array}{l}\text { ANOVA F(p) } \\
\text { Bonferroni test }\end{array}$ & $\mathrm{n}$ & Mean SD & $\begin{array}{l}\text { ANOVA F(p) } \\
\text { Bonferroni test }\end{array}$ \\
\hline \multirow[t]{3}{*}{3} & $1971^{\mathrm{a}}$ & 71 & 16.2 & 2.2 & $0.384(0.682)$ & 63 & 16.12 .5 & $3.986(0.020)$ \\
\hline & $2001^{d}$ & 84 & 16.2 & 1.8 & & 78 & 15.21 .8 & $\mathrm{a} / \mathrm{d}^{*}$ \\
\hline & $2011^{\mathrm{g}}$ & 114 & 16.4 & 2.1 & & 110 & 15.51 .8 & \\
\hline \multirow[t]{4}{*}{4} & $1971^{\mathrm{a}}$ & 124 & 17.8 & 2.5 & $0.952(0.415)$ & 114 & $\begin{array}{ll}18.0 & 2.7\end{array}$ & $2.564(0.078)$ \\
\hline & $2001^{d}$ & 123 & 18.0 & 2.4 & & 136 & $17.3 \quad 2.5$ & \\
\hline & $2011^{\mathrm{g}}$ & 129 & 17.9 & 2.6 & & 126 & 17.62 .1 & \\
\hline & $2017^{t}$ & 67 & 18.4 & 2.3 & & & & \\
\hline \multirow[t]{4}{*}{5} & $1971^{\mathrm{a}}$ & 190 & 21.0 & 2.9 & $3.273(0.021)$ & 167 & $20.2 \quad 2.9$ & $1.312(0.270)$ \\
\hline & $2001^{\mathrm{d}}$ & 161 & 20.1 & 3.0 & $\mathrm{a} / \mathrm{d}^{*}$ & 151 & 19.94 .2 & \\
\hline & $2011^{\mathrm{g}}$ & 124 & 20.2 & 3.7 & & 105 & $19.5 \quad 2.5$ & \\
\hline & $2017^{\mathrm{t}}$ & 159 & 20.7 & 2.8 & & - & - & \\
\hline \multirow[t]{4}{*}{6} & $1971^{\mathrm{a}}$ & 425 & 22.9 & 3.7 & $4.207(0,006)$ & 367 & $22.1 \quad 3.4$ & $1.024(0.360)$ \\
\hline & $2001^{\mathrm{d}}$ & 202 & 23.4 & 4.6 & & 194 & $22.4 \quad 4.0$ & \\
\hline & $2011^{\mathrm{g}}$ & 143 & 23.8 & 4.4 & & 138 & $22.6 \quad 3.8$ & \\
\hline & $2017^{\mathrm{t}}$ & 158 & 24.1 & 4.0 & $\mathrm{f} / \mathrm{a}^{* *}$ & - & - & \\
\hline \multirow[t]{6}{*}{7} & $1971^{\mathrm{a}}$ & 55 & 24.9 & 4.3 & $4.385(0.001)$ & 60 & 23.73 .7 & $5.503(0.000)$ \\
\hline & $1981^{b}$ & 352 & 25.6 & 3.8 & & 375 & $25.3 \quad 3.9$ & \\
\hline & $1991^{c}$ & 115 & 27.3 & 5.2 & $c / a^{*}$ & 110 & $26.4 \quad 4.5$ & $\mathrm{c} / \mathrm{a} * *$ \\
\hline & $2001^{\mathrm{d}}$ & 178 & 26.4 & 5.7 & & 164 & $25.0 \quad 4.7$ & \\
\hline & $2009^{e}$ & 60 & 27.4 & 4.5 & e/a* & 70 & 26.34 .6 & $\mathrm{e} / \mathrm{a} * *$ \\
\hline & $2017^{\mathrm{t}}$ & 127 & 26.1 & 4.2 & & 30 & $27.3 \quad 4.1$ & $\mathrm{f} / \mathrm{a}^{* *}$ \\
\hline \multirow[t]{6}{*}{8} & $1971^{\mathrm{a}}$ & 76 & 27.0 & 4.8 & $6.842(0.000)$ & 69 & $26.5 \quad 4.3$ & $4.116(0.001)$ \\
\hline & $1981^{b}$ & 774 & 28.7 & 5.3 & & 389 & 28.45 .2 & \\
\hline & $1991^{\mathrm{c}}$ & 113 & 30.2 & 6.1 & $\mathrm{c} / \mathrm{a}^{*}$ & 112 & 28.65 .7 & \\
\hline & $2001^{\mathrm{d}}$ & 160 & 29.4 & 5.8 & $d / a^{*}$ & 167 & $28.8 \quad 6.0$ & \\
\hline & $2009^{e}$ & 107 & 31.1 & 6.5 & $e / a, b * *$ & 102 & $30.0 \quad 5.1$ & $\mathrm{e} / \mathrm{a}^{*}$ \\
\hline & $2017^{\mathrm{t}}$ & 43 & 28.7 & 4.3 & & 30 & $30.2 \quad 6.8$ & $\mathrm{f} / \mathrm{a}^{*}$ \\
\hline \multirow[t]{6}{*}{9} & $1971^{\mathrm{a}}$ & 75 & 30.4 & 4.9 & $3.782(0.002)$ & 62 & 30.15 .6 & $3.493(0.004)$ \\
\hline & $1981^{b}$ & 410 & 31.6 & 5.7 & & 408 & 31.16 .1 & \\
\hline & $1991^{\mathrm{c}}$ & 114 & 31.6 & 4.8 & & 77 & $32.3 \quad 5.3$ & \\
\hline & $2001^{\mathrm{d}}$ & 164 & 32.0 & 7.3 & & 144 & $32.5 \quad 6.8$ & \\
\hline & $2009^{e}$ & 92 & 33.3 & 7.1 & e/a* & 85 & 33.67 .3 & $\mathrm{e} / \mathrm{a}, \mathrm{b} *$ \\
\hline & $2017^{t}$ & 32 & 34.9 & 7.0 & $\mathrm{f} / \mathrm{a}^{* *} ; \mathrm{f} / \mathrm{b}^{*}$ & 30 & $31.8 \quad 8.3$ & \\
\hline \multirow[t]{6}{*}{10} & $1971^{\mathrm{a}}$ & 64 & 33.5 & 5.0 & $3.464(0.004)$ & 54 & $32.5 \quad 5.4$ & $3.500(0.004)$ \\
\hline & $1981^{\mathrm{b}}$ & 410 & 35.4 & 7.2 & & 403 & 34.87 .1 & \\
\hline & $1991^{c}$ & 118 & 37.0 & 8.2 & $\mathrm{c} / \mathrm{a}^{*}$ & 126 & 36.68 .2 & $\mathrm{c} / \mathrm{a} * *$ \\
\hline & $2001^{\mathrm{d}}$ & 125 & 36.7 & 7.3 & & 110 & 36.68 .4 & $\mathrm{~d} / \mathrm{a} * *$ \\
\hline & $2009^{e}$ & 78 & 37.4 & 7.2 & e/a* & 106 & 35.37 .4 & \\
\hline & $2017^{\mathrm{f}}$ & 30 & 37.2 & 7.5 & & 30 & $36.1 \quad 3.7$ & \\
\hline \multirow[t]{6}{*}{11} & $1971^{\mathrm{a}}$ & 73 & 37.0 & 7.7 & $9.514(0.000)$ & 76 & $36.8 \quad 6.2$ & $4.528(0.000)$ \\
\hline & $1981^{\mathrm{b}}$ & 397 & 38.7 & 7.5 & & 380 & 39.37 .6 & \\
\hline & $1991^{\mathrm{c}}$ & 114 & 40.5 & 9.4 & & 98 & $39.8 \quad 8.6$ & \\
\hline & $2001^{d}$ & 89 & 37.4 & 7.1 & & 71 & 41.28 .9 & $\mathrm{~d} / \mathrm{a}^{* *}$ \\
\hline & $2009^{\mathrm{e}}$ & 85 & 42.9 & 9.1 & $\mathrm{e} / \mathrm{a}, \mathrm{b}, \mathrm{d} * * *$ & 92 & 41.98 .1 & $\mathrm{e} / \mathrm{a} * * * ; \mathrm{e} / \mathrm{b}^{*}$ \\
\hline & $2017^{1}$ & 65 & 43.2 & 9.0 & $\mathrm{f} / \mathrm{a}, \mathrm{b}, \mathrm{d} * * *$ & 71 & $39.4 \quad 6.1$ & \\
\hline
\end{tabular}


The weight means do not statistically differ among the boys aged 3 and 4 and the girls 4-6 years of age. Statistical difference is present in all other ages and the greatest values appear in 11-year-old boys $(\mathrm{F}=9.514 ; \mathrm{P}=0.000)$ and 7 -year-old girls $(\mathrm{F}=5.503 ; \mathrm{P}=0.000)$. The greatest increase in weight is observed in boys aged $11(6.2 \mathrm{~kg})$ and girls aged 8 (3.6kg). Considering the 3-year-old subjects, the change in weight in the period 1971-2011 is positive in boys, while in girls it is negative, as the period 1971-2001 shows a significant decrease $(\mathrm{p}<0.05)$. The weight change in subjects aged $4-6$ is positive equaling 0.5 and 0.1 $\mathrm{kg}$ in boys and girls, respectively. In 5-year-old boys the weight values show significant decrease $(\mathrm{P}<0.05)$ in the period of 30 years $(1971-2001)$, while the opposite trend is observed in 6-year-old boys $(\mathrm{P}<0.01)$. In puberty age, the weight means significantly differ for all ages in both boys and girls. The overall increase in subjects aged 7-11 equals $3.5 \mathrm{~kg}$ in boys and $2.9 \mathrm{~kg}$ in girls. Considering the changes recorded between 1971 and 2017, the weight values show an upward trend, with an exception of the age of 5 of both boys and girls (Table 2).

\section{Discussion}

The means of height and weight in most decades are approximately the same or above $50^{\text {th }}$ percentile of the US data, compared with CDC 2012 US reference (Anthropometric Reference Data for Children and Adults: United States, 2007-2010). An exception to this refers only to the weight values of 10 and 11-year-old boys and girls, as the means are lower than 50 percentile of the US data. A secular upward trend for height and weight among children aged 3-11 could be observed, although the increase is not equally represented in all decades and in all ages. The rate of secular change in the mean height during the 5 decades (1971-2017) equals $1.04 \mathrm{~cm} / 0.11$ per decade and $3.52 \mathrm{~cm} / 0.70$ per decade for preschool and school boys, respectively. In girls, the recorded values are $0.58 \mathrm{~cm} / 0.11$ per decade for preschool girls and $2.76 \mathrm{~cm} / 0.55$ in school age. The rate of secular change in the mean weight during 46 years equals $0.50 \mathrm{~kg} / 0.1$ and $3.47 \mathrm{~kg} / 0.69$ per decade in case of preschool and school boys, and $0.14 \mathrm{~kg} / 0.028$ and 2.86 $\mathrm{kg} / 0.57$ per decade in preschool and school girls, respectively. These results indicate a modest secular increase, given that earlier research has indicated (Meredith, 1976) that since the end of the $19^{\text {th }}$ century, a secular increase in height has occurred in developed countries, with increments varying from 0.5 to $3 \mathrm{~cm}$ per decade. However,the results are consistent with previous research (Cole, 2000) which points out that the size of secular trend depends on the age of children, with less changes being observed in younger children. Secular trend of increasing height is less obvious in younger ages since the beginning of the adolescent growth starts after the age of 11, and the changes are more intense at that time. The same has been observed in the city of Novi Sad in the 46-year-long period. The largest height increase during the period from 1971 to 2017 was registered at the age of 11 in both sexes. Differences in secular trends in height by age have been observed in some earlier studies (Meredith, 1976; Roche, 1979), with the largest increases typically occurring between the ages of 9 and 13. Freedman et al (2000) found that the largest height increases occurred at the ages of 10 to 12 (girls) and 13 years (boys). Recent secular growth studies in China (Zong and Li, 2014) reported improvement in growth and it is more pronounced at puberty than at earlier or later ages. The increase in height at the age of 18 is already present in younger ages and the eventual increase in adult height is established during the first 2 years of life. Other studies (Chinn and Rona, 1987; Lindgren and Hauspie 1989) reported a larger secular height increase among boys than among girls, which is possibly due to differences in growth spurts. The same was seen in children in Novi Sad when we observe a total average increase for all examined years. 
The increase in height and weight recorded in most European (Danker-Hopfe and Roczen, 2000; Cole, 2003; Padez, 2003; Garcia and Quintana-Domeque, 2007) and World countries (Kagawa et al., 2011; Zong et al., 2015) was also observed in the city of Novi Sad in the periods 1971-1981 and 1981-1991. However, in the period between 1991 and 2001, and after 2001, both positive and negative changes were recorded. Lower values recorded in 2001 may reflect the change in living conditions. Gross domestic product and national income were increasing until 1980 and the situation in the country was stable until 1989. In 1990, however, a political and economic crisis started causing a rapid fall of living standards. In 1990 the gross domestic product equaled 41 billion dinars, while in 1993 it was 17 billion dinars (Serbian Statistical Annual 2002). The same was recorded in the neighboring Croatia (Jovanović et al., 2003) where the analysis showed that secular growth trend was absent between 1991 and 2003 and was negative for children aged from 2.5 to 4 years.

In the following decades, preschool children's height and weight show an increase between the period 2001 and 2011, however in the period 2011-2017 the height values decrease while the weight still increases. In case of schoolchildren, in the period between 2001 and 2009 as well as 2009 and 2017 the height shows an overall increase, although this trend is not equally applicable to all age groups, i.e. in some ages there is an observable decline. The schoolchildren's weight increases in the period 2001-2009, while its values decrease in the later period between 2009 and 2017. The findings could be explained by the change of political and economic situation in the country. In the period 2001-2008 Serbian gross domestic product increased (Jovanović-Gavrilović, 2009). Nevertheless, in 2007 the gross domestic product was levelled out to the values recorded in 1986 (Bošnjak, 2009). The average growth of GDP in Serbia in the period 2010-2016 approximately equaled $0.5 \%$, while in East-Central Europe it was around 2.5\% and in the neighbouring countries 2\% (Petrović et al., 2017). Prior to the growth, there were two decades of a constant decline in work productivity. In comparison with 1980, GDP in 2011 was lower by $29.3 \%$, the employment rate by $13.5 \%$ and work productivity by $18.4 \%$. The level of GDP was identical to the one recorded in 1976, while the employment rate and work productivity showed the same level as in 1976 and 1970, respectively (https://www.makroekonomija.org/0-miroslav-zdravkovic/ srbija-1955-2011-bdp-zaposlenost-i-produktivnost/).On the other hand, from 2001 to 2012, a relative price stability was established, but the inflation rate still remained high. The situation concerning poverty partially improved in the period after the year 2000, however, according to UNDP data, 25000 persons in Serbia were poor, and 3.1\% citizens were on the brink of poverty (http://socijalnoukljucivanje.gov.rs/en/undp-human-development-index-serbia-ranks77th/). Serbia's Human Development Index (HDI) value for 2015 was 0.776 which put the country in the high human development category. Between 1990 and 2015, Serbia's HDI value increased from 0.714 to 0.776 , an increase of 8.6 percent. However, Gross National Income (GNI) per capita decreased by about 15.6 percent between 1990 and 2015 (Human Development Report 2016). Serbia's 2015 HDI of 0.776 was above the average of 0.746 for countries in the high human development group and above the average of 0.756 for countries in Europe and Central Asia. Considering Europe, the countries close to Serbia in 2015 in HDI rank were Croatia and Belarus.

One of the limitations of the present study is certainly the fact that it included only children aged 3-11 for whom we had enough available data for the investigated period. Since the level of the secular trend is greatly dependent on the child's age and is higher in older age, especially during puberty, it is possible to assume that the secular trend in older children would be of greater intensity. Also,the analysis is focused on children in one town of the Republic of Serbia, and therefore the results are not applicable to the entire population. Novi 
Sad is the second most developed city in Serbia in which $31 \%$ of the total population of Serbia lives and $40 \%$ of employees who make up two thirds of the total and $50 \%$ of industrial income. It can be assumed that income inequality and regional differences in Serbia would probably cause a different magnitude of secular trend in other parts of the country.

A secular upward trend for height and weight among children aged 3-11 could be demonstrated, although the magnitude of secular changes in body height and weight was not stable. There were periods of increased and decreased intensity of acceleration. A secular upward trend in body height and weight was documented from 1971 to 1991. However, between 1991 and 2001 and after 2001 both positive and negative changes were recorded for-certain ages and decades. The secular increase in height and weight has been modest in Novi Sad sample, especially in preschool children. Such changes in body height and weight possibly reflect a very turbulent socio-economic and political situation in the country, which began in the 1990 s. The recovery after a recession period is usually slow, particularly in case of recessions with a financial crisis. It is therefore difficult to predict future trends concerning secular changes in younger children from Novi Sad.

Acknowledgements: The authors would like to thank all the children and their parents who voluntarily took part in the research without whom this study and its findings would not be possible. The authors are grateful to Dr Ljiljana Knežević (Faculty of Sciences, University of Novi Sad) for language revision.

Declaration of interest: The authors report no conflicts of interest. The authors alone are responsible for the content and writing of the paper.

\section{References}

Akachi, Y., Canning, D. (2007). The height of women in Sub-Saharan Africa: the role of health, nutrition, and income in childhood. Ann Hum Biol, 34:397-410.

Bogin, B. (1999). Patterns of human growth. Cambridge University Press, Cambridge.

Bošnjak, M. (2009). Reforma realnog, finansijskog i javnog sektora u tranzicionom periodu 20012008. godine. In Tranzicija u Srbiji i globalna ekonomska kriza. Edited by Cerović B. and Kovačević M. Ekonomski fakultet u Beogradu.

Božić-Krstić, V. (1983). Prilog proučavanju nekih faktora od značaja za rast i razvoj dece i omladine. Doktorska disertacija. Univerzitet u Novom Sadu, Prirodno-matematički fakultet, Novi Sad.

Božić-Krstić, V., Rakić, R., Pavlica, T., Savić, M. (2000). Rast i razvoj učenika u Novom Sadu. Zbornik radova, drugi i treći simpozijum sa međunarodnim učešćem: Efekti različitih modela nastave fizičkog vaspitanja na psihosomatski status dece i omladine. Univerzitet u Novom Sadu, Fakultet fizičke kulture, Novi Sad.

Božić-Krstić, V., Pavlica, T., Rakić, R. (2004). Body height and weight of children in Novi Sad. Ann Hum Biol 31(3): 356-363.

CDC Monitoring the Nation's Health. 2012. Anthropometric reference data for children and adults: United States, 2007-2010. US Department of health and human services. Centers for disease control and prevention, National Center for Health Statistics. Series 11, Number 252.

Chinn, S., Rona, R.J. (1987). Secular trends in weight, weight-for-height and triceps skinfold thickness in primary schoolchildren in England and Scotland from 1972 to 1980. Ann HumBiol 14: 311-319.

Cole, T.J. (2000). Secular trends in growth. Proceedings of the Nutrition Society 59:317-324.

Cole, T.J. (2003). The secular trend in human physical growth: a biological view. EconHumBiol. $1(2): 161-8$.

Danker-Hopfe, H., Roczen, K. (2000). Secular trends in height, weight and body mass index of 6year-old children in Bremerhaven. Ann Hum Biol 27: 263-270.

Deaton, A. (2007). Height, health and development. Proc Natl Acad Sci USA 104:13232-13237. 
Freedman, D.S., Kettel Khan, L., Serdula, M.K., Srinivasan, S.R., Berenson, G.S. (2000). Secular trends in height among children during 2 decades. Arch Pediatr Adolesc Med 154: 155-161.

Garcia, J., Quintana-Domeque, C. (2007). The evolution of adult height in Europe: a brief note. Econ Hum Biol 5: 340-349.

Gavrilović, Ž. (1972). Prilog proučavanju visine i težine tela dece školskog uzrasta iz centra i sa periferije u Novom Sadu. Zbornik Matice srpske 43:99-107.

Gavrilović, Ž., Stajić, N., Božić, V. (1972). Neke antropometrijske karakteristike dece predškolskog uzrasta iz Novog Sada. Zbornik Matice srpske 42:173-190.

Jovanović, H., Prebeg, Z., Stanić, I., Vuletić, G.(2003).Impact of war on growth patterns in school children in Croatia. Coll Antropol 27(2): 573-579.

Jovanović-Gavrilović, B. (2009). Globalna kriza, kvaliteti privrednog rasta i tranzicija u Srbiji in Tranzicija u Srbiji i globalna ekonomska kriza. Edited by Cerović B. and Kovačević M. Ekonomski fakultet u Beogradu.

Kagawa, M., Tahara, Y., Moji, K., Nakao, R., Aoyagi, K., Hills, A.P. (2011). Secular changes in growth among Japanese children over 100 years (1900-2000). Asia Pac J ClinNutr 20: 180-189.

Komlos, J. (ed.) (1994). Stature, Living Standards, and Economic Development. Essays in Anthropometric History. Chicago: The University of Chicago Press.

Krawczynski, M, Walkowiak, J, Krzyzaniak, A. (2003) Secular changes in body height and weight in children and adolescents in Poznan, Poland, between 1880 and 2000. ActaPaediatr 92:277-282.

Lindgren, G.W., Hauspie, R.C. (1989). Heights and weights of Swedish school children born in 1955 and 1967. Ann Hum Biol 16: 397-406.

Lohman, T., Roche, A., Martorell, E. (1988). Anthropometric standardization reference manual. Champaign:Human Kinetics 177 p.

Malina, R,M. (1990). Research on secular trend on auxology. Anthrop Anz 48:209-218.

Meredith, H,V. (1976). Findings from Asia, Australia, Europe, and North America on secular change in mean height of children, youths and young adults. Am J Phys Anthropol 44: 315-326.

Neyzi, O., Bundak, R., Günöz, H., Darendeliler, F., Saka, N. (1996). Social class differences and secular trend in height in Turkish schoolchildren. In Bodzar B.E. and Susanne C. (eds), Studies in Human Biology. Eotvos University Press: Budapest, pp. 139-146.

Padez, C. (2003). Secular trend in stature in the Portuguese population (1904-2000). AnnHum Biol 30: 262-278.

Petrović, P., Brčerević, D., Minić, S. (2017). Fiskalna konsolidacija i privredni rast 2015-2017: Plan, ostvarenja i pokretači. Fiskalni savet Republike Srbije 2017. Tekst objavljen u Ekonomija preduzeća broj 65.

Rakić, R. Značaj nekih faktora sredine na rast i razvoj dece i adolescenata u Vojvodini. Doktorska disertacija, Univerzitet u Novom Sadu, PMF Departman za biologiju i ekologiju 2009:166p.

Rao, S., Kanade, A.N., Joshi, S.B., Sarode, J.S. (2012). Secular trends in growth of preschool children from rural Maharashtra, India. J Health Popul Nutr 30(4): 420-430.

Roche, A,F. (1979). Secular trends in stature, weight and maturation. Monogr Soc ResChild Develop 44: 3-27.

Serbian Statistical Annual (2002). Republika Srbija, Republički zavod za statistiku, Beograd, Opštine u Srbiji, Društveni proizvod i narodni dohodak, pp 467, 122-123.

Zellner, K,. Jaeger, U., Kromeyer-Hauschild, K (2004) Height, weight and BMI of schoolchildren in Jena, Germany-are the secular changes levelling off? Econ HumBiol 2:281-294.

Zong, X.N., Li, H. (2014). Physical growth of children and adolescents in China over the past 35 years. Bull World health Organ 92(8): 556-564.

Zong, X.N., Li, H., Wu, H.H., Zhang, Y.Q. (2015). Socioeconomic development and secular trend in height in China. Econ Hum Biol 19: 258-264.

United Nations Children's Fund WHO, The World Bank. UNICEF-WHO-World Bank, (2012) Joint Child Malnutrition Estimates. UNICEF, New York; WHO, Geneva; The World Bank, Washington, DC.

Weiner, J.S., Lourie, J.A. (1969). Human Biology a Guide to Field Method. Oxford: International Biological Program 
Serbia ranks 77 out of 187 countries in Human Development Index: http://www.rs.undp.org/content/serbia/ en/home/presscenter/pressreleases/2014/07/24/serbia-ranks-77-out-of-187-countries-in-humandevelopment-index-.html. Last accessed: 26 March 2018.

Human development report 2016. Human Development for Everyone. Briefing note for countries on the 2016 Human Development Report. Available at: http://hdr.undp.org/sites/all/themes/hdr_theme/ country-notes/SRB.pdf. Last accessed: 26 March 2018.

UNDP Human Development Index: http://socijalnoukljucivanje.gov.rs/en/undp-human-developmentindex-serbia-ranks-77th/. Last accessed: 26 March 2018.

Program razvoja AP Vojvodine http://www.region.vojvodina.gov.rs/upload/Program_razvoja_AP_ Vojvodine_2014_2020_3891.pdf. Last accessed: 26 March 2018.

Zdravković M.: Srbija 1955-2011: BDP, zaposlenost i produktivnost. Makroekonomija, Ekonomske analize, Srbija, okruženje i međunarodna ekonomija. https://www.makroekonomija.org/0-miroslavzdravkovic/srbija-1955-2011-bdp-zaposlenost-i-produktivnost/. Last accessed: 26 March 2018.

http://www.politika.rs/scc/clanak/112039/Dunavsko-savska-koncentracija. Last accessed: 26 March 2018.

\title{
SEKULARNI TREND VISINE I MASE TELA KOD DECE U NOVOM SADU (SRBIJA), 1971-2017
}

\author{
Tatjana M. Pavlica, Rada S. Rakić, Boris K. Popović, \\ Valerija P. Puškaš, Verica S. Božić-Krstić
}

Sažetak. Sekularni trend je biološki indikator kojim se može proceniti socio-ekonomski razvoj zemlje.
Cilj rada je bio da se utvrdi sekularni trend visine i mase tela kod dece od $3-11$ godina u
Novom Sadu (Srbija), u periodu između 1971 i 2017 godine. Antropometrijsko istraživanje je
urađeno u 6 vremenskih perioda. Ukupno je ispitano 13037 dece (6969 dečaka; 6068
devojčica) na teritoriji Novog Sada. Rezultati ukazuju na pozitivan sekularni trend, mada to
nije uočeno u svim godištima i dekadama. Prosečna visina predškolskih dečaka i devojčica
se povećala za $0.21 \mathrm{~cm}$ i $0.11 \mathrm{~cm}$ po dekadi, dok je kod dečaka i devojčica školskog uzrasta
povećanje po dekadi iznosilo $0.70 \mathrm{~cm}$ i $0.55 \mathrm{~cm}$.Prosečno povećanje mase tela predškolskih
dečaka i devojčica iznosilo je $0.1 \mathrm{~kg}$ i $0.03 \mathrm{~kg}$, dok je kod školske dece prosečno povećanje
iznosilo $0.69 \mathrm{~kg}$ (dečaci) i $0.57 \mathrm{~kg}$ (devojčice) po dekadi. Veličina sekularnih promena visine i
mase tela nije stabilna. Ovakvi rezultati možda reflektuju veoma turbulentnu socio-
ekonomsku i političku situaciju u zemlji, koja je započela 1990-ih godina.

Ključne reči: Deca, visina, masa, sekularni trend, Srbija. 